\title{
DIMENSI PENGURANGAN PRASANGKA DALAM PENDIDIKAN AGAMA ISLAM
}

\section{Sugiyar \\ Doktor PAI Multikultural Pascasarjana Unisma}

E-mail: sugiyarbwi@yahoo.com

\begin{abstract}
Abstrak
Pengurangan prasangka (prejudice reduction) merupakan salah satu dimensi pendidikan multikultural. Multikultural sesungguhnya mengenali keragaman di sekitar individu agar dapat memahami suatu perbedaan sebagai sunatullah. Perbedaan memiliki peran penyeimbang yang baik dalam kehidupan, manakala setiap individu dapat menerimanya berdasarkan fitrahnya. Multikultural beragama didasarkan pada nilai-nilai universal yang diakui dan dianut oleh setiap pemeluk agama. Nilai-nilai tersebut membentuk pola hubungan yang harmonis dan humanis antar umat seagama maupun antar umat beragama. Keberagaman harus dirawat dan dijaga agar tidak memunculkan konflik sosial. Terjadinya konflik sosial disebabkan banyak faktor, diantaranya ketidakadilan, kesenjangan sosial, maupun adanya kecurigaan (prasangka buruk) terhadap orang lain. Prasangka buruk dapat memicu dan menimbulkan disharmoni relasi sosial. Membangun dan menciptakan lingkungan yang harmonis, toleran, humanis, dan demokratis diperlukan keseimbangan olah pikir, olah rasa, dan olah hati.
\end{abstract}

Kata kunci: dimensi, prasangka, pendidikan agama Islam

\section{Abstract}

Prejudice reduction is one of the dimensions of multicultural education. Multiculturalism actually recognizes the diversity around individuals in order to understand a difference as sunatullah. Difference has a good balancing role in life, when each individual can accept it based on their nature. Religious multiculturalism is based on universal values that are recognized and embraced by every religious adherent. These values form a pattern of harmonious and humanist relationships between people of the same faith and between religious communities. Diversity must be cared for and maintained so as not to create social conflicts. The occurrence of social conflicts is caused by many factors, including injustice, social inequality, and suspicion (prejudice) against others. Bad prejudice (سوء الظن) can trigger and cause disharmony in social relations. Building and creating a harmonious, tolerant, humanist, and democratic environment requires a balance of thought, feeling, and heart.

Keywords: dimensions, prejudice, Islamic religious education PENDAHALUAN 
Dimensi pengurangan prasangka (prejudice reduction) dalam PAI menjadi basis utama dalam penerapan dimensi-dimensi pendidikan multikultural lainnya. Oleh karenanya, dimensi ini diletakan pada bagian awal sebagai pondasinya. Dimensi pengurangan prasangka bertujuan untuk menata hati agar memiliki kesalehan secara individu maupun sosial. Islam memerintahkan untuk menjauhi berburuk sangka terhadap orang lain. Menjauhi buruk sangka tidak hanya sesama muslim, akan tetapi terhadap nonmuslim.

Pendidikan multikultural memberikan perspektif dan keyakinan tentang perbedaan manusia. "Keluarga, komunitas, teman sebaya, dan media dipengaruhi oleh identitas yang berkaitan dengan ras, etnis, bahasa, gender, kelas sosial, jenis kelamin, dan agama. Identitas dapat difahami sebagai narasi yang dibangun seseorang tentang dirinya dalam hubungan dengan orang lain dan pada situasi sosial tertentu."1 Pendidikan multikultural diharapkan mampu memberikan akses dan peluang terhadap identitas secara adil. Pendidikan multikultural mempunyai 5 (lima) dimensi yang meliputi: (1) integrasi materi (content integration); (2) proses konstruksi pengetahuan (the knowledge construction process); (3) pengurangan prasangka (prejudice reduction); (4) pendidikan yang adil (an equity pedagogy); dan (5) pemberdayaan budaya sekolah (an empowering school culture). ${ }^{2}$

Multikultural dalam beragama pada dasarnya membangun paradigma keberagamaan yang inklusif, toleran, dan moderat. Pendidikan multikultural dalam konteks beragama mengkaji agama, hubungan antar umat seagama dan antar umat beragama, nilai-nilai universal dalam agama, hubungan antara agama dengan kultur dan kearifan lokal (local wisdom). ${ }^{3}$ Agama perlu dikaji secara mendalam dan komprehensif untuk memperoleh pemahaman yang benar, sehingga mampu menerapkannya dalam kehidupan.

Selanjutnya Arifin menegaskan bahwa multikultural sejatinya adalah memahami perbedaan dapat diterima secara natural dan tidak menimbulkan

${ }^{1}$ Carl A. Grant and Christine Sleeter, Doing Multicultural Education for Achievement and Equity (USA: Taylor \& Francis Group, 2007), 14.

2 James A. Banks and Cherry A. McGee Banks, Multicultural Education: Issues and Perspectives, 7th ed. (USA: John Wiley \& Sons, Inc., 2010), 20-23. Lihat dalam James A. Banks, The Routledge International Companion to Multicultural Education (New York: Routledge, 2009), 15-16.

3 Imron Arifin, "Pendidikan Multikultural Perespektif Keagamaan dan Kultural", dalam Asep Sunandar, Prof. Son Sang Pendidik Multikultural, Cet. I (Malang: Intelegensia Media, 2015), 85. 
tindakan diskriminatif. ${ }^{4}$ Pendidikan Islam berbasis multikultural berlandaskan pada nilai-nilai, antara lain: ${ }^{5}$ nilai andragogi, nilai perdamaian, ${ }^{6}$ nilai inklusifisme, nilai toleransi, nilai humanis, dan nilai kebebasan tentang setiap manusia memiliki hak yang sama di hadapan Allah Swt.

\section{A. Tujuan Penelitian}

Sekolah kejuruan identik dengan pencapaian bidang keahlian bagi siswanya. Di sisi lain diperlukan penguatan basis Pendidikan Agama Islam (PAI) di tengah-tengah masyarakat multikultural. Implementasi kurikulum PAI seringkali dihadapkan pada problem dalam berbagai dimensi pencapaian kompetensinya. Penelitian ini bertujuan untuk menemukan pola pembentukan kesalehan multikultural pada siswa di Sekolah Menengah Kejuruan Negeri (SMKN) 1 Geger Madiun dan SMK al-Islam Joresan Ponorogo.

\section{B. Metode Penelitian}

Penelitian ini adalah penelitian kualitatif dan desain penelitian studi kasus. Teknik pengumpulan data dengan wawancara, observasi, dan dokumen. Teknik analisis data menggunakan model Creswell, meliputi: mengorganisasi data, membaca data, mengode data, melaporkan temuan, menginterpretasi temuan, dan memvalidasi akurasi temuan. Selanjutnya dilakukan analisis lintas kasus pada kedua situs penelitian. Pengecekan keabsahan data menggunakan triangulasi.

\section{Kajian Teori}

\section{Adab sebagai Basis dalam Mencari Ilmu}

Pendidikan bertujuan untuk meningkatkan kualitas dan membentuk karakter siswa sehingga mampu beradaptasi dengan lingkungannya. Pencapaian tujuan pendidikan dilakukan melalui proses pembelajaran الأدب ( الأبan didasari dan diali dengan adab sebelum mengikuti proses tersebut (قبل الطلب (Adab dan sopan santun sebagai sikap dan perilaku untuk memperoleh keberkahan ilmu. ${ }^{7}$ Ibnu Hajar mengatakan bahwa: "adab

${ }^{4}$ Asep Sunandar, Prof. Son Sang Pendidik Multikultural, Cet. I (Malang: Intelegensia Media, 2015), 85.

${ }^{5}$ Yaya Suryana and A. Rusdiana, Pendidikan Multikultural: Suatu Upaya Penguasaan Jati Diri Bangsa, Konsep, Prinsip, Implementasi (Bandung: Pustaka Setia, 2015), 323-26.

${ }^{6}$ Maksum and Ruhendi, Paradigma Pendidikan Universal, 272.

${ }^{7}$ al-Imam al-Qadhi Badruddin Muhammad bin Ibrahim bin Sa'dillah Ibn Jama'ah, Tadzkirah Al-Sami' Wa Al-Mutakallim Fii Adab Al-'Alim Wa Al- 
adalah penggunaan hal yang terpuji baik ucapan dan tindakan.” Seyogyanya seorang murid membekali diri dengan keutamaan etika dan akhlak mulia. ${ }^{8}$ Adab berkaitan erat dengan syari'at, iman, dan tauhid. ${ }^{9}$

Adab ada dua macam yaitu adab kepada Allah Swt dan adab terhadap hamba-Nya. ${ }^{10}$ Ibnu Atha'illah menggambarkan tentang kondisi awal dan akhir seseorang "من أثرقت بدايته، أشرقت نهايته", "barangsiapa permulaannya terang benderang, maka demikian halnya pada akhirnya." 11

Muta'alim, I’tana bihi Muhammad bin Mahdi al-'Azmy, Cet. III (Beirut-Libanon: Dar al-Basyair al-Islamiyah, 2012), 9.

${ }^{8}$ Abdullah bin Shalih al-Fauzan, Minhah Al-'Allam Fi Syarh Bulugh AlMaram, Juz X, Cet. I (Qahirah: Dar Ibn al-Jauzy, 1432), 5-6. Lihat Abu al-Hasan Ali bin Abi Bakr bin Sulaiman al-Syafi'i Nur al-Din al-Haitsami, Majma'u AlZawaid Wa Manba'u Al-Fawaid, Juz XVI, Tahqiq wa Takhrij Husein Salim Asad al-Darani, Cet. I (Jeddah: Dar al-Minhaj, 2015), 34-36. Abu Bakar bin Muhammad Syatha al-Dimyati, Kifayah Al-Atqiya' Wa Minhaj Al-Ashfiya' (Surabaya: alHidayah, .), 84. Keterkaitan ilmu dan adab, adab dapat menghantarkan pada

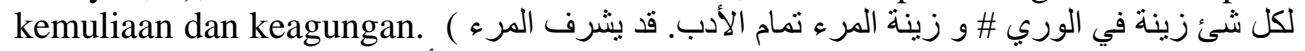
(بأدابه \# فينا و ان كان وضيع النسب.

${ }^{9}$ al-Syeikh Muhammad Hasyim al-Asy'ari al-Jumbangi, Adab Al-'Alim Wa Al-Muta'allim, Cet. I (Jombang: Maktabah al-Turats al-Islami, 1415), 11.

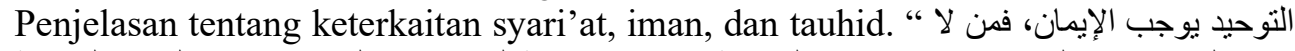

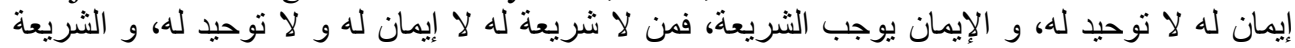

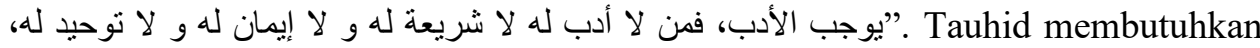
iman, maka barangsiapa tidak punya iman tidak punya tauhid. Dan iman membutuhkan syari'at, barangsiapa tidak punya syari'at tidak ada iman baginya dan tidak punya tauhid. Syari'at membutuhkan adab, barangsiapa tidak punya adab, tidak punya syari'at, tidak punya iman, dan tidak punya tauhid.

${ }^{10}$ Muhammad bin Shalih al-'Utsaimin, Fath Dzi Al-Jalal Wa Al-Ikram Bi Syarh Bulugh Al-Maram, Juz VI, Tahqiq wa Ta'liq Shubhi bin Muhammad Ramadhan wa Ummu Isra' binti Arafah Baiyumi, Cet. I (Qahirah: al-Maktabah alIslamiyah, 2006), 237. Adab kepada Allah Swt. melaksanakan ketaatan dan mengangungkan-Nya. Adab terhadap hamba Allah Swt adalah berbuat kebaikan, sikap terpuji, dan etika sosial.

11 Ibnu 'Abbad al-Naffazi al-Rundi, Al-Hikam Al-'Athai'iyah Li Ibn 'Athaillah Al-Sakandari, I'dad wa Dirasah Muhammad Abd al-Maqshud Haikal, Cet. I (Qahirah: Mu'asasah al-Ahram, 1988), 154. Lihat Ibnu 'Abbad al-Naffazi alRundi, Syarh Al-Hikam Ala Matn Al-Hikam Li Imam Ahmad Bin Muhammad Bin Abdil Karim Ibn Atha'illah Al-Sakandari, n.d., 25-26. Memanfaat waktu untuk senantiasa taat kepada Allah Swt, sehingga pada akhirnya ia akan memperoleh cahaya dan pengetahuan serta hilangnya kotoran hati. Lihat Muhammad Hayah alSindi al-Madani, Syarh Al-Hikam Al-Athaiyah, Tahqiq Nizar Hamadi, Cet. I (Beirut-Libanon: Dar Maktabah al-Ma'arif, 2010), 30. Barang siapa menanam ia akan menuai pada akhirnya. Barang siapa permulaannya dengan sunnah, pada 30 
Segala bentuk usaha, ketaatan, dan amal perbuatan baik pada awalnya, maka menuai hasil baik pada akhirnya. Setiap kebaikan manusia tidak akan lepas dari adanya kesalahan dan ketidaksempurnaan. ${ }^{12}$ Niat yang baik mendorong sikap positif dan dapat meminimalisir buruk sangka.

Tawadhu', rasa ingin tahu yang tinggi, sabar, lemah-lembut, mengikuti petunjuk guru, dan tujuan utama mencari ilmu merupakan adab murid terhadap guru. Digambarkan dalam al-Qur'an kisah Nabi Musa dan Nabi Khidir. ${ }^{13}$ Dengan ketinggian kedudukan Nabi Musa (كليم الله), ia tetap patuh mengikuti persyaratan (tidak menanyakan sesuatu apapun, dan Nabi Khidir memberikan penjelasan) yang diajukan Nabi Khidir untuk

akhirnya ia istiqamah. Dan barang siapa permulaaannya dengan bid'ah, pada akhirnya ia tertipu. Lihat Ahmad bin Muhammad bin 'Ajibah al-Hasani, Iqadh AlHimam Fii Syarh Al-Hikam, Taqdim wa Muraja'ah Muhammad Ahmad Hasabullah (Kairo: Dar al-Ma'arif, n.d.), 101. Bersandar kepada Allah Swt, menyerahkan dirinya kepada-Nya, ia memperoleh keagungan. Dan lihat Muhammad Khalil al-Khatib al-Nidi, Kasyf Al-Ghitha': Syarh Wa Tartib Wa Nadhm Hikam Sayyidi Ahmad Bin Athailah Al-Sakandari (Daar al-Basyirah li alTsaqafah wa al-Ulum, n.d.), 112. Melakukan ketaatan kepada Allah Swt. memperoleh cahaya dan pengetahuan.

12 al-Hasani, Iqadh Al-Himam Fii Syarh Al-Hikam, 607. Ungkapan dalam munajat: “إلهي من كانت محاسنه مساوي فكيف لا تكون مساويه مساوي". Seseorang berperilaku baik saja dianggap salah, apalagi ia berbuat salah, tentu jelas salahnya.

${ }^{13}$ Muhammad Amin al-Kurdi, Tanwir Al-Qulub Fi Mu'amalah Allam AlGhuyub, Taqdim Abdullah Mas'ud, Cet. I (Suriah: Dar al-Qalam al-Arabi, 1991), 599-602. Beberapa tata krama atau adab seorang murid menunggu penjelasan dari guru dari sesuatu yang tidak diketahui, diantaranya ada sesuatu tidak logik yang dilakukan oleh guru. Namun hal ini ada rahasia dibalik sesuatu yang dilakukan guru, menghindari konflik dengan guru dan ada kalanya secara dhahirnya haram. و لا تعثرض فيما جهلت من أمره \# عليه فإن الاعتر اض تنازع. و سلم له فيما تراه و إن يكن \# لعلي غير )

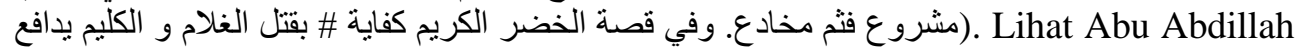
Muhammad bin Isma'il bin Ibrahim bin al-Mughirah al-Ja'fi al-Bukhari, Shahih Bukhari: Al-Jami' Al-Musnad Al-Shahih, Juz I (Beirut-Libanon: Dar al-Ta'shil, 2012), 248-49. HR. Bukhari No. 75 menjelaskan sebab terjadi pertemuan Nabi Musa dan Nabi Khidir. 
memperoleh ilmu. ${ }^{14}$ "Prasangka mendekatkan seseorang cenderung bersikap dan berperilaku negatif dan penuh kebohongan." 15

\section{Dimensi Pengurangan Prasangka (Prejudice Reduction)}

Dimensi pengurangan prasangka (prejudice reduction) merupakan bagian upaya pembentukan moral siswa. Istilah prasangka pada dasarnya bersifat polemik berfungsi untuk melegitimasi pendapat, tesis, atau teori yang subjeknya tidak disebarluaskan, tetapi lebih meragukan. ${ }^{16}$ Prasangka dalam psikologi sosial digambarkan tentang diskriminasi, etnosentrisme, kelompok favorit, kelompok tidak fair, kelompok di luar kepatutan (outgroup derogation), kelompok oposisi, stereotip, dan orang yang berjarak secara sosial. Berdasarkan pandangan ini, prasangka secara tradisional dapat difahami, sebagai: (a) orientasi negatif terhadap anggota kelompok tertentu; (b) buruk dan tidak dapat dibenarkan; (c) tidak rasional dan salah; dan (d) kaku. ${ }^{17}$

Prasangka tidak rasional disebabkan tidak terlihat ada keterkaitan dengan realitas. Allport mendefinisikan prasangka "tanpa surat perintah yang memadai" (without sufficient warrant) ${ }^{18}$ atau kegagalan rasionalitas ( $a$ failure of rationality). ${ }^{19}$ Beberapa pendapat tentang prasangka: prasangka

14 Yusuf al-Qardhawi, Al-Aql Wa Al-Ilm Fi Al-Qur'an Al-Karim, Cet. I (Qahirah: Maktabah Wahbah, 1996), 227-31. Kedudukan Nabi Musa lihat dalam Q.S. al-A'raf [7:144]; Q.S. al-Baqarah [2:253]; dan Q.S. al-Nisa' [4:164]. Perjalanan Nabi Musa dan Nabi Khidir lihat dalam Q.S. al-Kahfi [18:65-82]. Lihat Yusuf Qardhawi, Al-Qur'an Berbicara Tentang Akal Dan Ilmu Pengetahuan, "al'Aql wa al-Ilm fii al-Qur'an al-Karim", terj. Abdul Hayyi al-Khattani, Irfan Salim, dan Sochimien, Cet. I (Jakarta: Gema Insani Press, 1998), 255-60.

15 Muhammad Muhammad Tamar, Muqaddimah Al-Imam Al-Nawawi: Li Kitab Al-Majmu’ Syarh Al-Muhadzab, Cet. I (Kairo: Maktabah al-Balad al-Amiin, 1999), 50. Penjelasan tentang mengetahui sesuatu dengan benar agar tidak terjadi prasangka yang dapat menimbulkan pembicaraan yang penuh dengan kebohongan. و ولا تباغضو او لا تدابروا و كونوا :Hadits Abu Hurairah berkata, bersabda Rasulullah Saw إياكم و الظن، فإنه أكذب الحديث و لا تحسسو ا ولا تجسسو ا عباد الله إخو انا

16 Pierre-André Taguieff, The Force of Prejudice: On Racism and Its Doubles, Translated and edited by Hassan Melehy (London: The University of Minnesota Press, 2001), 144.

${ }^{17}$ Martha Augoustinos and Katherin J. Reynold, Understanding Prejudice, Racism, and Social Conflict (London: Sage Publication Inc, 2001), 2. 1954), 7.

${ }^{18}$ G. W. Allport, The Nature of Prejudice, Reading (MA: Addison-Wesley,

19 J. Proshansky Harding, H.M. Kuter B., and Chein, "Prejudice and Ethnic Relations," Reading MA; Addison Wesley, The Handbook of Social Psychology, 
adalah sumber kesalahan (Francis Bacon \& René Descartes), prasangka adalah sumber ketidakadilan (Adam Smith), dan prasangka sebagai sumber perbudakan (Immanuel Khant). ${ }^{20}$

Dimensi pengurangan prasangka (prejudice reduction) berkaitan dengan sikap dan perilaku guru, tenaga kependidikan, dan siswa dalam interaksi sosial di lingkungan sekolah. Munculnya prasangka dapat dipengaruhi oleh perbedaan perspektif terhadap orang lain dengan latar belakang berbeda. Secara akademik guru memiliki perbedaan pandangan karena latar belakang pendidikannya. Demikian juga terjadi pada tenaga kependidikan yang ikut membantu secara tidak langsung berjalannya proses pendidikan di sekolah. Siswa memiliki perbedaan latar belakang, baik secara ekonomi, pendidikan, budaya, agama, bahasa, etnis, gender, dan bahasa menjadi perhatian guru dan tenaga kependidikan dalam mengelola perbedaan dalam interaksi dan proses edukatif.

Nilai berprasangka berasal dari banyak sumber (resources) dan pengaruh (influences). Sumber prasangka dapat berasal dari media yang secara efektif memperkuat sikap seseorang, prasangka muncul dalam lingkungan keluarga, dan kurangnya interaksi dengan orang lain yang berbeda-beda. Dan kebanyakan orang mencari cara untuk menunjukkan bahwa dirinya tidak berprasangka pada dirinya sendiri dan orang lain. ${ }^{21}$

Menurut Allport pengurangan prasangka dapat dilakukan dengan menunjukkan empat syarat utama dalam membangun komunikasi antar kelompok, yaitu: "(a) kesetaraan status; (b) bersikap kooperatif daripada persaingan, (c) pemberian sanksi dari yang memiliki otoritas, dan (d) interaksi antar pribadi." 22 Kesetaraan status berkenaan dengan perlakuan terhadap siswa dengan keragaman latar belakangnya, baik bahasa, budaya, agama, gender, maupun etnis. Membangun sikap kerjasama yang baik dalam interaksi edukasi dan interaksi sosial, tidak menunjukkan adanya

Vol.5 (1969): 6. Lihat dalam Augoustinos and Reynold, Understanding Prejudice, Racism, and Social Conflict, 2.

${ }^{20}$ Adam Adatto Sandel, The Place of Prejudice: A Case for Reasoning Within The World (USA: Harvard University Press, 2014), 24-53.

${ }^{21}$ Kristin J. Anderson, Benign Bigotry: The Psychology of Subtle Prejudice (New York: Cambridge University Press, 2010), 9.

22 Allport, The Nature of Prejudice. Lihat dalam James A. Banks and Cherry A. McGee Banks, Multicultural Education: Issues and Perspectives, 7th ed. (USA: John Wiley \& Sons, Inc., 2010), 21-22. Lihat dalam Rupert Brown, Prejudice: Its Social Psychology, 2nd. ed. (United Kingdom: John Wiley \& Sons Inc, 2010), 244-48. Lihat dalam Mary E. Kite and Bernard E. Whitley, Jr, Psychology of Prejudice and Discrimination, 3rd. ed. (New York: Routledge, 2016), 537. 
bentuk-bentuk persaingan mencolok. Setiap adanya pelanggaran tata tertib yang telah disepakati, maka akan memperoleh sanksi dari yang berhak memberikannya.

\section{Terbentuknya Kesalehan Multikultural}

Kesalehan merupakan lawan dari kerusakan. Individu yang shaleh yaitu pelaku kesalehan terhadap diri sendiri dan kesalehan dalam amal dan perbuatan. Kesalehan dimulai dengan adanya niat yang baik dalam dengan dilandasi nilai-nilai mulia. Niat baik berasal dari hati yang shaleh. Kesalehan hati ada dua macam, yaitu: niat baik individu dan aksi kebaikan صلاح القلوب، ضربان: أحدها: قاصد كالمعرفة و الإيقان. و الثاني متعد كإر ادة الجود و ” "sosial ". 23

Sekolah sebagai sebuah organisasi yang ideal dapat digambarkan dengan adanya aturan yang didasarkan pada nilai-nilai (values). Nilai yang menjadi kesepakatan dan pedoman bersama untuk diterapkan di lingkungan sekolah dan masyarakat sekitar pada umumnya. Aturan-aturan (rules) yang diterapkan dilandasi dengan nilai (values) secara jelas, diantaranya: “(a) kejujuran dan keadilan (fairness), aturan yang diterapkan pada setiap orang secara adil; (b) kejelasan (clarity), aturan yang diterapkan sedapat mungkin sederhana dan jelas; (c) kebijaksanaan (discretion), aturan yang memungkinkan untuk melaksanakan kebijaksanaan dengan tepat; (d) kesepakatan (agreement), aturan dibagi secara luas dan tujuannya jelas; (e) dapat dikerjakan (workability), aturan dapat diikuti dan ditegakkan; dan (f) kewenangan (authority), aturan dilaksanakan oleh pihak memiliki otoritas." 24

Allah Swt menciptakan manusia untuk melakukan pengabdian kepada-Nya. ${ }^{25}$ Konsep pengabdian merupakan penghambaan kepada Allah

${ }^{23}$ Sulthan al-Ulama Izzuddin bin Abdissalam bin Hasan al-Sulami and alAllamah Izzuddin bin Abdissalam bin Ghanam al-Maqdisi, Syajarah Al-Ma'arif Wa Al-Ahwal Wa Shalih Al-Aqwal Wa Al-A'mal, Tahqiq Ahmad Farid al-Mazidi, Cet. I (Beirut-Libanon: Dar al-Kutub al-Ilmiah, 2003), 12. Lihat Ibnu Qayyim alJauziyah, Al-Fawaid (Maktabah al-Riyadh al-Haditsah, n.d.), 112. Beberapa hal yang tidak bermanfaat, diantaranya: hati yang kosong dari cinta Allah, rindu kepada-Nya, dan menyukai-Nya (و قلب فارغ من محبة الله و الثوق إليه و الأنس به), ilmu tanpa amal, maupun amal tanpa keikhlasan. Lihat Muhammad bin Ibrahim alTuwaijiri, Mausu'ah Fiqh Al-Qulub, Juz II (Jordan: Bait al-Afkar al-Dauliyah, 2006), 1285.

${ }^{24}$ Robert Goffee and Gareth Jones, Why Should Anyone Work Here?: What It Takes to Create an Authentic Organization (Boston: Harvard Business Review Press, 2015), 182.

${ }^{25}$ Lihat Q.S. al-Dzariyat [51:56] tentang penciptaan jin dan manusia untuk mengabdi kepada Allah Swt. Pengabdian atau penghambaan dengan menjalankan ibadah. 
Swt. Al-Ghazali menjelaskan penyucian jiwa (تزكية النفس) pada diri manusia melalui: (a) pembersihan jiwa (تخلي) yakni mengosongkan jiwa dari perbuatan tercela; (b) memperindah jiwa (تحلي) sebagai tahapan mengisi jiwa dengan akhlak terpuji; dan (c) membangun hubungan baik dengan Allah Swt (تجلي), sehingga tersingkap tabir mendorong jiwa mudah menerima nur ilahi berupa petunjuk dan pertolongan-Nya. Menurut Ibnu Taimiyah pembersihan jiwa dapat tercapai dengan: (a) iman dan tauhid; (b) mengikuti jejak Rasul Saw; dan (c) menjalankan kewajiban dan perkaraperkara sunnah. ${ }^{27}$

Ayat di atas menjelaskan tentang: pertama, membacakan ayat-ayatNya (يتلو ا عليكم آيتنا). Hal ini dijelaskan tentang membaca al-Qur'an ${ }^{28}$ maupun perintah berbuat baik dan menjauhi larangan. ${ }^{29}$ Kedua, menyucikan jiwa

${ }^{26}$ al-Imam Abi Hamid bin Muhammad bin Muhammad al-Ghazali, Ihya' Ulum Al-Diin, Juz II, Bi Qalam Badawi Thabanah (Semarang: Karya Toha Putra, n.d.), 355. Lihat Q.S. al-Syams [91:7-10] artinya: "Dan jiwa serta penyempurnaannya (ciptaannya). Maka Allah mengilhamkan kepada jiwa itu (jalan) kefasikan dan ketakwaannya. Sesungguhnya beruntunglah orang yang mensucikan jiwa itu, dan sesungguhnya merugilah orang yang mengotorinya." Lihat dalam Abi al-Abbas Ahmad bin Abd al-Halim Ibnu Taimiyah, Fashl Fii Tazkiyah Al-Nafs, I'tana bih Fawwaz Muhammad al-'Audhi, Ct. I (Kuwait: Maktabah al-Nahj al-Wadhih, 2018), 12. Mensucikan jiwa dengan meninggalkan sesuatu yang haram dan menjalankan sesuatu yang diperintah. Menurut Sufyan bin 'Uyainah dan Qatadah bahwa mensucikan diri yaitu dengan taat kepada Allah Swt dan amal perbuatan baik (shaleh). Dan Q.S. Ali Imran [4:164].

${ }^{27}$ Abi al-Abbas Ahmad bin Abd al-Halim Ibnu Taimiyah, Tazkiyah AlNafs, Dirasah wa Tahqiq Muhammad bin Said bin Salim al-Qahthani, Cet. I (Riyadh: Dar al-Muslim, 1994), 16.

${ }^{28}$ Muhammad Jamal al-Din al-Qasimi, Mahasin Al-Ta'wil, Cet. I (Dar Ihya al-Kutub al-Arabiyah, 1957), 662. Lihat al-Allamah al-Syeikh Muhammad bin Umar Nawawi al-Jawi, Marah Labid Li Kasyf Ma'na Al-Qur'an Al-Majid, Juz I, Dhabathahu wa Shahahu wa Wadha'a Hawasyih Muhammad Amiin al-Dhanawi, Cet. I (Beirut-Libanon: Dar al-Kutub al-Ilmiah, 1997), 52. Lihat Abu Ja'far Muhammad bin Jarir al-Thabari, Tafsir Al-Thabari: Jami' Al-Bayan 'an Ta'wil Ai Al-Qur'an, Juz II, Tahqiq Abdullah bin Abd al-Muhsin al-Turki, Cet. I (Qahirah: Markaz al-Buhuts wa al-Dirasat al-Arabiyah wa al-Islamiyah, 2001), 694. Lihat Abu Ishaq Ahmad bin Muhammad bin Ibrahim al-Tsalabi, Al-Kasyf Wa Al-Bayan Fi Tafsir Al-Qur'an, Juz I, Tahqiq Sayyid Kasrawi Hasan, Cet. I (Beirut-Libanon: Dar al-Kutub al-Ilmiah, 2004), 215. Lihat Yaqut al-Hamawi al-Rumi, Mu'jam AlUdaba': Irsyad Al-Arib Ila Ma'rifah Al-Adib, Tahqiq Ihsan Abbas, Cet. I (BeirutLibanon: Dar al-Gharb al-Islami, 1993), 1416. Membaca ayat-ayat al-Qur'an

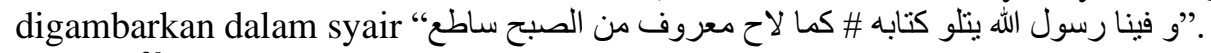

29 Haji Abdulmalik Abdulkarim Amrullah, Tafsir Al-Azhar, Jilid I (Singapura: Pustaka Nasional, 1982), 345. 
(يزكيكم) dari akhlak yang buruk, jiwa yang kotor, perbuatan jahiliyah, serta keluar dari kegelapan menjadi terang ${ }^{30}$ dan membersihkan dari syirik, ${ }^{31}$ serta menumbuhkan akhlak yang baik dan adab terpuji. ${ }^{32}$ Ketiga, mengajarkan alKitab dan al-Hikmah (يعلمكم الكتب و الحكمة) dilakukan setelah mengosongkan (التخلي) dari syirik dan keraguan untuk mengikutinya. ${ }^{33}$ Al-Hikmah adalah Sunnah ${ }^{34}$ maupun syari'at dan penjelasan hukum. ${ }^{35}$

Dalam masyarakat plural diperlukan kesalehan multikultural, yaitu kesalehan individu dan kesalehan sosial yang berdimensi terbuka melampaui batas-batas etnis, kebangsaan, faham keagamaan, dan kepemelukan suatu agama. ${ }^{36}$ Bentuk kesalehan multikultural yaitu: (a) kesalehan autentik (kesalehan etik) merupakan amal perbuatan baik manusia yang didorong kesadaran dirinya sebagai pilihan; (b) kesalehan profetik berkaitan dengan pengelolaan gerakan untuk merealisasikan kebaikan Islam bagi semua orang; dan (c) kesalehan madani sebagai gerakan sosial dan kebudayaaan atau peradaban. ${ }^{37}$ Manusia profesional menunjukkan pada pribadi yang memiliki kesalehan spiritual dan kesalehan sosial.

30 al-Hafidz Ibnu Katsir, Umdah Al-Tafsir, Juz I, Tahqiq Ahmad Syakir, Cet. II (Dar al-Wafa, 2005), 197.

${ }^{31}$ Shihab al-Din al-Sayid Mahmud al-Alusi al-Baghdadi, Ruh Al-Ma'ani Fi Tafsir Al-Qur'an Al-Karim Wa Al-Sab’i Al-Matsani, Juz II (Beirut-Libanon: Dar Ihya al-Turats al-'Arabi, n.d.), 18.

${ }^{32}$ Muhammad Fakhr al-Din al-Razi, Tafsir Al-Fakhr Al-Razi, Juz IV, Cet. I (Beirut-Libanon: Dar al-Fikr, 1981), 158. Lihat Ahmad Musthafa al-Maraghi, Tafsir Al-Maraghi, Juz II, Cet. I (Kairo: Musthafa Al-Babi Al-Halabi, 1946), 18. Lihat Muhammad Abduh and Muhammad Rasyid Ridha, Tafsir Al-Manar, Juz II, Cet. II (Qahirah: Dar al-Manar, 1947), 27.

33 al-Alusi al-Baghdadi, Ruh Al-Ma'ani Fi Tafsir Al-Qur'an Al-Karim Wa





34 Muhammad Abu Zahrah, Zahrah Al-Tafasir (Qahirah: Dar al-Fikr alArabi, 1987), 24. Lihat Abu al-Faraj Jamal al-Din bin Abdurrahman bin Ali bin Muhammad al-Jauzi, Zad Al-Masir Fi Ilm Al-Tafsir, Cet. I (Beirut-Libanon: Dar Ibnu Hazm, 2002), 95. Lihat Mujir al-Din bin Muhammad al-'Ulaimi, Fath AlRahman Fi Tafsir Al-Qur'an, Juz I, Tahqiq wa Takhrij Nuruddin Thalib, Cet. I (Beirut: Dar al-Nawadir, 2009), 225.

35 Saraf al-Din al-Husein bin Abdillah al-Thibi, Futuh Al-Ghaib Fi AlKasyf an Qina' Al-Raib, Juz III, Tahqiq Umar Hasan al-Qiyam, Cet. I (Dubai: alImarat al-Arabiyah al-Muttahidah, 2013), 93.

${ }^{36}$ Mulkhan, Kesalehan Multikultural, 7.

${ }^{37}$ Mulkhan, 10-29. 


\section{Temuan dan Pembahasan \\ 1. Prasangka yang Baik}

Masyarakat memandang eksistensi sekolah kejuruan dan siswanya kurang baik. Siswa SMK dipersepsikan berasal dari anak-anak yang "nakal". Kondisi semacam ini mendorong sekolah untuk membuat terobosan dan kebijakan dalam membentuk pribadi siswa yang baik. Salah satu jawaban untuk menepis kesan ini adalah pendidikan agama Islam sebagai alternatif solusi. ${ }^{38}$ Pendidikan Agama Islam (PAI) memiliki peran penting, diantaranya adalah pembentukan karakter siswa. Ini sebagai modal utama dalam belajar maupun kehidupan sosial di sekolah, masyarakat, atau keluarga. ${ }^{39}$

Pendidikan agama dan keagamaan menjadi perhatian guru sejak dini agar siswa memiliki pengetahuan agama dan mampu mengamalkannya. Kemajuan teknologi perlu diimbangi dengan landasan keagamaan yang kuat agar tidak salah dalam menggunakannya. Pembiasaan perilaku keagamaan akan membentuk karakter siswa yang baik. Bidang keahlian menjadi tujuan utama (main purpose) sekolah vokasional, namun tidak melalaikan perhatian pada bidang agama bagi muslim maupun nonmuslim. Agama membentuk sikap dan perilaku manusia dalam berbuat kebaikan. Membangun hubungan yang baik dengan Tuhan dan sesama makhlukNya. ${ }^{40}$

Pembiasaan merupakan proses habituasi pada siswa dalam kehidupan sehari-hari, terutama di sekolah. Kegiatan religius dilakukan secara rutin dan berkelanjutan menjadi media internalisasi pengamalan keagamaan. Setiap pagi, sebelum proses pembelajaran berjalan, semua peserta didik masuk kelas dan guru pada jam pertama sudah siap di ruang kelas untuk membaca al-Quran. Setelah selesai kegiatan apel pagi ada satu petugas yang akan memandu membaca al-Qur'an dari kantor pusat. Setiap pagi anak-anak membaca dua lembar dari juz 30, selama durasi waktu yang digunakan lima sampai sepuluh menit. Sementara siswa yang di kelas didampingi oleh guru, mereka membaca sendiri mengikuti panduan dari kantor." 41

Tujuan kegiatan Taruna adalah melatih ketahanan mental dan fisik. Ketahanan mental dilatih dan dibangun melalui kegiatan keagamaan. Desain model pendidikan agama Islam diintegrasikan dalam kegiatan Taruna. Biasanya kegiatannya dimulai dengan aktivitas keagamaan di masjid, mulai

\footnotetext{
${ }^{38}$ Wawancara dengan M. Nasrudin, pada 19 September 2018.

${ }^{39}$ Wawancara dengan Nur Hadi, pada 24 Oktober 2018.

${ }^{40}$ Wawancara dengan Supriyadi, pada 03 Oktober 2017.

${ }^{41}$ Wawancara dengan Sri Lestari, pada 12Nopember 2018.
} 
shalat dhuha, membaca dan menghafal ayat-ayat al-Quran, serta diberikan ceramah singkat motivasi dari dalil-dalil yang dipilih. Selanjutnya mereka melanjutkan kegiatan di lapangan atau di tempat lain sesuai dengan jadwal yang ditetapkan. Semua kelas mendapat giliran untuk melaksanakan kegiatan ini sehari penuh dalam tiap minggunya. ${ }^{42}$

Kegiatan bidang kerohanian taruna adalah salah satu bidang kegiatan ketarunaan yang wajib diikuti oleh semua anggota taruna tanpa terkecuali dengan mengikuti tata cara dan aturan-aturan yang ada. Untuk membentuk dan membiasakan anggota taruna untuk selalu tertib dan taat beribadah sesuai dengan agamanya. Melatih disiplin dan kesabaran dalam beribadah. Menanamkan nilai-nilai moral agar tumbuh menjadi karakter. Membangun mindset untuk menciptakan iklim religius di sekolah ini. ${ }^{43}$

"Pembiasaan tertib disiplin dalam kegiatan kerohanian, mulai berwudu', saat adzan, sholat, berdzikir, membaca al-Qur'an, menghafal surat-surat pendek, ataupun tausiyah. Materi dalam tausiyah atau ceramah disesuaikan dengan pembina yang membimbing kegiatan. Materi tiap hari mesti berbeda, karena pembina dan siswa taruna juga berbeda. Kita buat fleksibel saja. Kegiatan ini mengajak anak-anak untuk membiasakan diri ke masjid, sehingga mereka bisa merasa nyaman. Dengan demikian, dengan akan tumbuh kesadaran mereka sendiri dalam menjalankan kegiatan kerohanian dengan baik. Pembiasaan-pembiasaan yang dilakukan selama ini menjadi bekal mereka di kemudian hari setelah lulus sekolah. Ketika mereka sudah lulus dan bekerja, berbaur dengan banyak orang, misalnya diminta menjadi imam shalat, mereka tidak merasa canggung, meski lulusan SMK. Saya yakin ini menjadi bekal utama dalam kehidupan mereka sebenarnya." 44

Memahami keragaman dalam komunitas sekolah dapat dilakukan dengan berfikir positif atau berprasangka baik. Prasangka baik seseorang terhadap orang lain akan menumbuhkan sikap dan perilaku positif dalam interaksi sosial serta dapat menghilangkan kecurigaan-kecurigaan. ${ }^{45}$ Nilai utama (core values) transparansi dapat menggurangi kecurigaan atau prasangka antar sesama warga sekolah dan tetap terjalin hubungan harmonis dan saling menghormati. ${ }^{46}$ Keterbukaan dilakukan dalam pengambilan

42 Wawancara dalam diskusi grup (Supriyadi, Sumadi, M. Nasrudinn, dan Udin Sasmita), pada tanggal 12 Desember 2017.

${ }^{43}$ Wawancara dengan Nur Hadi, pada 24 Oktober 2018.

44 Wawancara dengan Udin Sasmita, pada 12 September 2018 dan Wawancara dengan Sumadi, pada 19 September 2018.

${ }^{45}$ Wawancara dengan siswa (Devina, Febia, dan Fani), pada 08 Mei 2019.

${ }^{46}$ Wawancara dengan Sumadi, pada 19 September 2018. 
kebijakan, keputusan, dan interaksi warga sekolah. ${ }^{47}$ Islam menganjurkan orang beriman untuk menjauhi prasangka buruk, mencari-cari kesalahan orang lain, maupun mengunjing terhadap yang lain. ${ }^{48}$

Larangan menjauhi prasangka buruk bertujuan agar terhindar dari dosa dan perbuatan maksiat lainnya. Prasangka baik (حسن الظن) mendorong seseorang bersikap dan berperilaku baik terhadap sesuatu yang dilakukan orang lain. Prasangka baik merupakan akhlak mulia kepada Allah Swt, orang lain, maupun pada diri sendiri. Seseorang berprasangka kepada Allah, maka sejatinya ia menerima sesuai dengan apa yang disangkakan kepadaNya. ${ }^{49}$ Sikap dan perilaku yang baik terhadap orang lain sebagai bentuk nyata berprasangka baik. sebaliknya, prasangka buruk dapat menimbulkan dusta atau kebohongan pada orang lain. ${ }^{50}$ Hadits Nabi Saw menerangkan berburuk sangka (سوء الظن) merupakan perkataan yang paling dusta, yaitu:

$$
\text { إياكم و الظن، فانن الظن أكذب الحديث (رواه البخاري) }
$$

"Jauhkanlah dirimu dari prasangka buruk, karena sesungguhnya prasangka itu adalah perkataan yang paling dusta." (H.R. Bukhari)

Prasangka baik sejatinya membentuk hubungan harmonis manusia dengan Tuhannya dan sesama makhluk. Hubungan sesama manusia dalam satu keyakinan dapat terjalin dengan baik. Persaudaraan dalam Islam dimaksudkan adalah persaudaraan yang diikat dengan keimanan. ${ }^{51}$ Persaudaraan ini sebagai jalinan sesama mukmin dalam hubungannya dengan Allah Swt untuk saling berbuat kebaikan. Fungsi sosial manusia dalam kehidupan sebagai sesama makhluk Tuhan perlu dijalin dengan baik sebagai mitra kemanusiaan. Pola kemitraan kemanusiaan untuk membangun hubungan harmonis untuk menciptakan kedamaian dan kerukunan antar sesama. Q.S. Hujurat [49:10]:

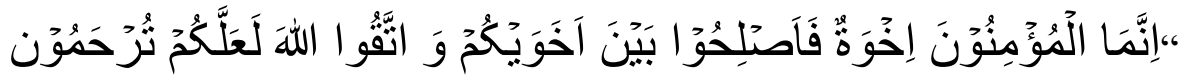

${ }^{47}$ Wawancara dengan M. Nasrudin, pada 19 September 2018.

${ }^{48}$ Dokumen Kurikulum 2013 Materi PAI \& BP kelas X.

${ }^{49}$ Dokumen KTSP kelas X.

${ }^{50}$ Dokumen Kurikulum 2013 kelas X.

${ }^{51}$ Dokumen Kurikulum 2013. Dalam buku PAI \& BP kelas X Kurikulum

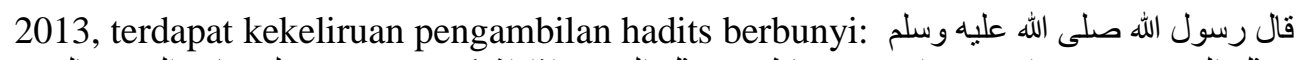

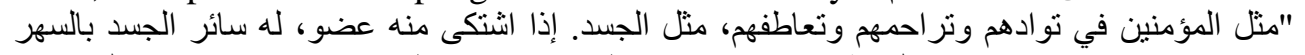

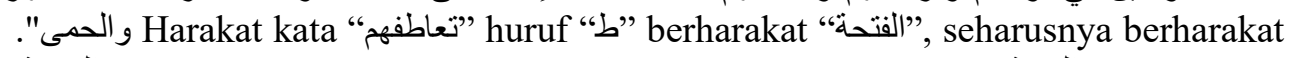

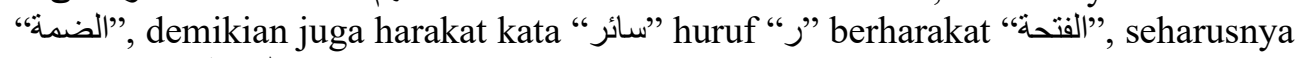
berharakat “"الضماعى" tidak ada dalam hadits tersebut. (Buku Paket PAI \& BP Kelas X, halaman 96). 
"Orang-orang beriman itu sesungguhnya bersaudara. sebab itu damaikanlah (perbaikilah hubungan) antara kedua saudaramu itu dan takutlah terhadap Allah, supaya kamu mendapat rahmat."

Penanaman etika terhadap siswa dilakukan sejak dini melalui penyampaian materi-materi PAI dan pembiasaan dalam keseharian di طلب ( sekolah maupun di luar sekolah. ${ }^{52}$ Adab atau etika dalam mencari ilmu (العلم menjadi perhatian utama. Kondisi saat ini memiliki tantangan luar biasa dalam upaya menanamkan sikap dan perilaku baik agar terbentuk kepribadian teguh dalam kehidupan sosialnya. Materi dalam kitab تعليم المتعلم merupakan salah satu bagian yang mengajarkan tentang sikap dan perilaku terhadap guru, ilmu, maupun tata cara dalam mencari ilmu. Etika siswa dalam mencari ilmu ditumbuhkembangkan agar memperoleh keberkahan dan manfaat ilmu. ${ }^{53}$

Penanaman akhlak mulia (الأخلاق الكريمة) kepada siswa agar mampu menempatkan diri dimana saja dan kapan saja dengan perangai yang baik. Ilmu terapan merupakan sebaik-baik ilmu, dan sebaik-baik amal adalah menjaga tindakan (أفضل العلم علم الحال \# و أفضل العمل حفظ الحال). Beberapa bagian yang diajarkan, yaitu: hakikat ilmu dan fiqh, niat ketika belajar, dan memilih ilmu, guru, teman, dan tabah. ${ }^{54}$ Akhlak dalam memulai belajar, diantaranya menghormati guru maupun kitab-kitab. Kajian materi dilanjutkan dengan tema: mengagungkan ilmu dan ahli ilmu, bagian tentang bersungguh-sungguh, ketekunan/keajegan (المواظبة), dan semangat kuat (الهمة); dan bagian yang menerangkan permulaan belajar, ukuran, dan urutanya. ${ }^{55}$

Materi-materi dalam PAI mengajarkan pendidikan akhlak. Diantaranya materi yang disajikan dalam beberapa mata pelajaran, yaitu: pertama, materi al-Qur'an dan materi al-Hadits dalam kitab karya Ibnu Hajar al-'Asqalani yaitu بلوغ المرام. Dalam Q.S. al-Hujurat [49: 10-13] yang menjelaskan tentang: (1) seorang mukmin itu bersaudara (saudara dalam keimanan), membangun hubungan baik karena takwa kepada Allah Swt; (2) sikap seorang mukmin adalah tidak merendahkan orang lain, tidak mencela diri sendiri (sesama muslim), tidak memanggil dengan gelaran yang buruk, dan segera kembali kepada Allah Swt agar tidak menjadi orang yang dhalim; (3) seorang mukmin diperintahkan untuk menjauhi purba-sangka (kecurigaan), mencari-cari keburukan saudaranya ataupun mengunjingkannya; dan (4) penegasan asal muasal manusia dan dijadikannya dalam

\footnotetext{
${ }^{52}$ Wawancara dengan Ahmad Suyono, pada 30 Oktober 2018.

${ }^{53}$ Wawancara dengan Siska, pada 21 April 2019.

${ }^{54}$ Wawancara dengan K. Syamsuddin, pada 03 Februari 2019.

${ }^{55}$ Wawancara dengan K. Slamet Zuhdi, pada 02 Februari 2019.
} 
berbangsa-bangsa dan bersuku-suku untuk saling mengenal (لتعارفوا) di antara mereka. ${ }^{56}$

Muslim membangun persaudaraan dengan menghindarkan diri dari saling dengki, saling menipu, saling marah, ataupun saling membelakangi. Sikap dan perilaku ini akan menimbulkan permusuhan dan konflik dalam masyarakat. Selain itu, muslim menghidarkan diri dari prasangka buruk. Prasangka buruk muncul dari munculnya isu-isu yang belum tentu kebenarannya (قيل و قال). Sikap berprasangka baik dilakukan secara terusmenerus akan memunculkan energi positif. ${ }^{57}$

Menghindarkan diri dari berburuk sangka dengan saling mengenal orang lain dengan baik. Saling mengenal dapat menciptakan interaksi sosial yang baik, namun sebaliknya manakala tidak mengenal satu sama lain akan terjadi disharmoni sosial (الأرواح جنود مجندة إذا تعارف ائتلف و إذا تناكر اختلف).58 Selanjutnya seseorang akan memahami orang lain dengan baik pula, sehingga menemukan kecocokan dan mampu mempersatukan mereka dalam komunitas sosial. Kecocokan di antara mereka mendorong keterbukaan untuk saling berbagi. Dengan demikian, prasangka buruk akan hilang dengan sendirinya.

\section{Nilai-nilai dalam Pendidikan Agama Islam (PAI)}

Dalam kajian materi al-Qur'an, Hadits, akidah, akhlak, maupun sejarah peradaban Islam sebagai sarana untuk memahami nilai-nilai mulia, pengambilan pelajaran (lesson learned) ataupun keteladanan (القدوة الحسنة). Nilai-nilai mulia dalam pendidikan agama Islam yang diajarkan di sekolah, meliputi: menjauhi buruk sangka, toleransi, demokrasi, etos kerja, berlaku adil, jujur, menghormati orangtua dan guru, bertanggung jawab, dan sifatsifat terpuji lainnya. ${ }^{59}$ Demokrasi sebagai jembatan untuk mempertemukan keragaman manusia untuk saling menghargai, saling menghormati, dan saling menjaga eksistensinya. Nilai-nilai dalam berdemokrasi mencakup: sikap toleran, lemah-lembut, saling memaafkan, dan berserah diri kepada Allah Swt. ${ }^{60}$

${ }^{56}$ Wawancara dalam grup fokus (Nurkham, Fahrurozi, dan Khoirul Anwar), pada 20 September 2018.

${ }^{57}$ Wawancara dengan Ahmad Suyono, pada 30 Oktober 2018.

${ }^{58}$ Wawancara dengan Abdul Khabib, pada 30 Oktober 2018.

${ }^{59}$ Wawancara dengan Febya, pada 12 November 2018.

${ }^{60}$ Dokumen Kurikulum 2013 kelas XII dan Dokumen Kurikulum 2013. Lihat dalam Q.S. Ali Imran [3:159]: " Maka disebabkan rahmat dari Allah-lah kamu berlaku lemah lembut terhadap mereka. Sekiranya kamu bersikap keras lagi berhati kasar, tentulah mereka menjauhkan diri dari sekelilingmu, karena itu ma'afkanlah mereka, mohonkanlah ampun bagi mereka, dan bermusyawaratlah 
Sikap utama dalam menuntut ilmu (طلب العلم) adalah menghormati orang tua dan guru. Islam menganjurkan untuk menyayangi dan menghormati kedua orang tua. Kesempurnaan ibadah kepada Allah Swt dengan berbuat baik kepada kedua orang tua, berkata dengan perkataan yang baik (قو لا كريما), dan berbuat kepadanya dengan penuh kasih sayang. ${ }^{61}$ Doa utama seorang anak kepada kedua orang tuanya: " رب ارحمهما كما ربينى الصغيرا". Demikian juga anjuran Rasulullah Saw untuk berbuat baik kepada kedua orang tua, misalnya keridha'an orang tua maupun berbakti kepada orang tua (بر الوالدين) sebagai amalan yang dicintai Allah Swt. Guru adalah orangtua siswa yang mengajarkan ilmu pengetahuan, mendidik akhlak, dan membimbingnya. Memuliakan dan menghormati guru merupakan adab dalam menutut ilmu, sehingga keberkahan ilmu akan diperoleh.

\section{Penerapan Tata Tertib}

Sekolah memiliki tata tertib dan menerapkannya terhadap warga sekolah. Siswa sebagai subjek dan objek utama penerapan tata tertib. Tujuan penerapan tata tertib adalah untuk melatih dan membiasakan siswa disiplin dalam kegiatan-kegiatan di sekolah. Implementasi tata tertib dilakukan melalui tahapan sosialisasi kepada warga sekolah, termasuk orangtua siswa. Tahapan ini dimaksudkan agar tidak terjadi kesalahfahaman dan upaya membangun transparansi dalam penerapan tata tertib. Selanjutnya internalisasi tata tertib dengan melakukan pembiasaan-pembiasaan dalam kegiatan siswa di sekolah maupun di luar sekolah.

Sarana untuk merumuskan dan membuat kebijakan adalah musyawarah. Berbagai usulan untuk membuat suatu kebijakan dapat berasal dari bawah atau dari atas. Keterlibatan wakil kepala sekolah untuk melakukan perbaikan atau penyempurnaan rumusan kebijakan (tata tertib). Kebijakan yang sudah final disosialisasikan kepada seluruh warga sekolah. Keterlibatan karyawan, guru, maupun siswa dalam menjalankan kebijakan yang telah dibuat. Bilamana ada pelanggaran agar saling mengingatkan "ngelekne" sebagai konsekuensi logis dari aturan yang telah dibuat dan disepakati bersama. ${ }^{62}$

Prinsip penerapan tata tertib adalah reward and punishment. Prinsip reward dikedepankan sebagai bentuk apresiasi perbuatan baik. Sementara punishment diberikan dalam bentuk poin bagi pelanggar tata tertib, baik di dalam kelas maupun di luar kelas. Keterlibatan warga sekolah dalam

dengan mereka dalam urusan itu, kemudian apabila kamu telah membulatkan tekad, maka bertawakkallah kepada Allah. Sesungguhnya Allah menyukai orangorang yang bertawakkal kepada-Nya."

${ }^{61}$ Dokumen Kurikulum 2013 kelas X.

${ }^{62}$ Wawancara dengan Edy Susanto, pada 24 Oktober 2018. 
penyampaian laporan pelanggaran melalui aplikasi atau secara manual dengan $\mathrm{BCP} .{ }^{63}$ Setiap siswa diberi $\mathrm{BCP}$ yang berisi tata tertib, poin pelanggaran dan reward. Mereka memiliki aplikasi yang dapat mengakses informasi poin maupun reward. dengan mudah. Mereka tidak diberi hukuman, melainkan diberi poin pelanggaran. ${ }^{64}$

Penerapan tata tertib memiliki konsekuensi bagi siswa berupa reward maupun poin. Siswa yang memperoleh reward dengan melakukan hal-hal baik, diantaranya: (a) mengumumkan penemuan uang; (b) tidak melakukan pelanggaran selama satu bulan ${ }^{65}$ (c) membersihkan kaca dan menyapu halaman; ${ }^{66}$ dan (d) melaksanakan piket dan mengikuti perlombaan. ${ }^{67}$ Siswa yang memperoleh reward lebih (tidak ada poin pelanggaran) akan diapresiasi dengan pemberian tugas sebagai petugas upacara ataupun pengurus kelas. Mereka yang memperoleh reward cukup banyak akan mendapatkan apresiasi berupa keikutsertaan dalam perlombaan atau diberi penghargaan, atau beasiswa.

Otoritas pemberi poin adalah para pihak yang terlibat dalam tim tata tertib (Tatib), diantaranya guru mata pelajaran, wali kelas, maupun pelatih ketarunaan. Guru BK memotivasi siswa untuk tidak melakukan pelanggaran. Ini menjadi perhatian BK agar siswa dapat merubah hal yang kurang baik menjadi baik atau bahkan lebih baik. Selain itu, BK yang melakukan "banding" atau pembelaan ketika siswa memperoleh poin. Misalnya, ada siswa yang datang terlambat, otomatis ia dapat poin keterlambatan. Padahal siswa terlambat karena menolong saudaranya, dan sebelumnya sudah memberitahukan kepada BK. ${ }^{68}$ Ibaratnya tatib itu "polisi" dan BK sebagai "jaksa". 69

\section{Mawas Diri (Muhasabah)}

Segala amal perbuatan yang dilakukan manusia akan diperhitungkan oleh Allah Swt. Amal perbuatan yang dilakukan secara terang-terangan maupun secara sembunyi-sembunyi tetap akan diperhitungkan. Manusia berusaha untuk mawas diri (المحاسبة) atas amal perbuatannya. ${ }^{70}$ Siswa diajari untuk introspeksi diri terhadap segala sesuatu yang telah diperbuat agar

\footnotetext{
${ }^{63}$ Wawancara dengan M. Nasrudinn, pada 11 Mei 2018.

${ }^{64}$ Wawancara dengan siswa, pada 08 Mei 2019.

${ }^{65}$ Wawancara Sri Sundari, pada 12 Nopember 2018.

${ }^{66}$ Wawancara dengan siswa nonmuslim, pada 12 Nopember 2018.

${ }^{67}$ Wawancara dengan Sri Sundari, pada 12 Nopember 2018.

${ }^{68}$ Wawancara dengan Basuki, pada 11 Oktober 2018.

${ }^{69}$ Wawancara dengan Udin Sasmita, pada 12 September 2018.

${ }^{70}$ Wawancara dengan Guru al-Qur'an, pada 20 September 2018.
} 
tetap terjaga dalam amalan yang baik. Ketentuan Allah Swt tentang ampunan dan adab diberikan kepada hamba yang dikehendaki-Nya.

Manusia bersyukur atas nikmat yang dikaruniakan Allah Swt kepadanya. Menumbuhkan rasa syukur dengan cara melihat kondisi orang lain yang berada di bawahnya. Manakala melihat kondisi orang lain yang berada di atasnya agar mampu menumbuhkan sikap semangat dan berusaha semaksimal mungkin dengan tetap menyandarkan kepada-Nya. Kedua sikap tersebut sebagai bentuk instrospeksi diri agar bisa menyadari betapa besar karunia Allah Swt yang dilimpahkan kepada makhluk-Nya. ${ }^{71}$

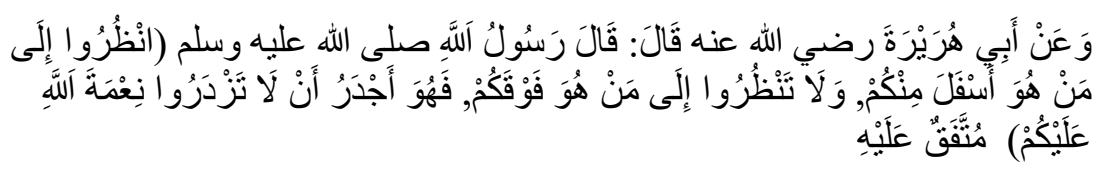

Dari Abu Hurairah ra bahwa Rasulullah Saw bersabda: "Lihatlah orang yang berada di bawahmu dan jangan melihat orang yang berada di atasmu karena hal itu lebih patut agar engkau sekalian tidak menganggap rendah nikmat Allah yang telah diberikan kepadamu." Muttafaq Alaihi. ${ }^{72}$

Berpikir positif sebagai cara berfikir secara logis dan rasional dalam memandang segala sesuatu dari perspektif positif, baik diri sendiri, orang lain atau lingkungan sekitar. Pikiran positif mendorong munculnya energi positif sehingga mampu mewujudkan tindakan positif. Salah satu contoh berfikir positif adalah mencermati substansi ucapan, bukan siapa yang mengucapkan (انظر ما قال و لا تنظر من قال). Ucapan yang baik dan mengandung makna dapat berasal dari siapa saja, bilamana dilihat secara positif. Kebaikan dan kebenaran dapat berasal dari berbagai latar belakang yang berbeda-beda. Ide dan gagasan orang lain, bilamana dilihat secara positif akan memberikan manfaat.

Manfaat berfikir positif adalah mendorong seseorang untuk melakukan introspeksi diri (المحاسبة). Ia akan memperlakukan orang lain sebagaimana ia memperlakukan dirinya sendiri, sehingga orang lain akan berbuat baik kepadanya. Introspeksi menjaga keseimbangan dalam melakukan suatu tindakan. Setiap orang memiliki kelebihan dan kekurangan. Sehingga ia akan menutupi kekurangan orang lain dan demikian juga sikap orang lain kepadanya. ${ }^{73}$ Berbuat baik terhadap diri أصلح ( أصلح (نفسك يصلح للك الناس).

\footnotetext{
${ }^{71}$ Wawancara dengan Ahmad Suyono, pada 30 Oktober 2018.

${ }^{72}$ Ibnu Hajar al-'Asqalani, Bulugh Al-Maram Min Adillah Al-Ahkam, 59091.

${ }^{73}$ Wawancara dengan Moh. Irham, pada 14 Nopember 2018. 
Materi pelajaran tata bahasa terkait tentang perubahan kata sesuai dengan makna yang dikehendakinya. Materi ini tercakup dalam mata pelajaran (الصرف). Perubahan kata mengikuti pola perubahan (الوزن) dalam setiap bentuk yang dikehendaki. Melihat pola perubahan dalam kata kerja yang terdiri dari tiga huruf (الفعل الثلاثي الهجرد). Kata kerja memiliki 6 (enam)

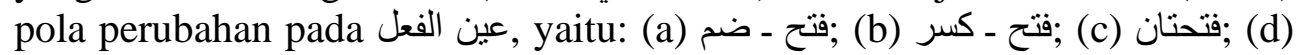
كسرتان (f) - ضم - ضم (e) Setiap kata kerja memiliki satu pola perubahan untuk makna yang dikehendaki. Enam pola perubahan tertata dalam urutan-urutan penggunaannya.

Secara filosofis tata urutan berkaitan dengan muhasabah dalam proses pembelajaran, antara lain: (1) menolong (نصر), setiap siswa siap menolong dirinya sendiri dalam belajar maupun pengerjaan tugas; (2) memukul (ضرب), siswa memperoleh kritik, saran, dan masukan; (3) membuka (فتح), sikap siswa membuka diri dan mau menerima saran maupun masukan; (4) menjadi tahu (علم), siswa memperoleh pengetahuan secara komprehensif; (5) berbuat baik (حسن), siswa membagusi diri dengan pengetahuan yang diperoleh untuk mewujudkan sikap dan perilaku yang baik; dan (6) menghitung (حسب), pada tahapan ini siswa dapat memperhitungkan kemampuan dirinya, melakukan introspeksi atau orang lain memperhitungkan kemampuannya untuk berkarya. ${ }^{74}$

Berdasarkan data lapangan ditemukan beberapa aspek dalam upaya pengurangan prasangka dalam Pendidikan Agama Islam (PAI), yaitu: (a) pembentukan moral keagamaan; (b) landasan religius; (c) nilai-nilai PAI; (d) mawas diri (muhasabah); dan (e) pelaksanaan tata tertib. Beberapa aspek tersebut diindikasikan dengan indikator-indikatornya sebagaimana ditampilkan pada tabel berikut:

\begin{tabular}{|c|l|l|}
\hline \multicolumn{1}{|c|}{ Aspek } & \multicolumn{1}{|c|}{ SMKN 1 Geger } & \multicolumn{1}{c|}{ SMK al-Islam Joresan } \\
\hline & - Pendidikan Agama & - Eksistensi SMK di bawah \\
& Islam dijadikan & naungan pondok pesantren \\
& alternatif solusi & memberi pesan bekal religius \\
& dalam pembinaan & siswa yang cukup \\
Pembentukan & akhlak siswa & - Kajian utama akhlak melalui \\
moral & - Guru membekali & Kitab Ta'lim al-Muta'allim \\
keagamaan & siswa dengan & - Pembiasaan kegiatan \\
& pengetahuan & keagamaan, diantaranya: \\
& agama & membaca al-Qur'an, shalawat \\
& - Pembiasaan & nariyah, meng-hafal ayat-ayat \\
& kegiatan & dan surat pilihan, maupun \\
\hline
\end{tabular}

${ }^{74}$ Wawancara dengan Moh. Supriyadi, pada 17 Maret 2019. 


\begin{tabular}{|c|c|c|}
\hline & $\begin{array}{l}\text { keagamaan, } \\
\text { diantaranya: } \\
\text { membaca al- } \\
\text { Qur'an, shalat } \\
\text { Dhuha, maupun } \\
\text { shalat Dhuhur. } \\
\text { - Pembiasaan pada } \\
\text { kegiatan Taruna } \\
\text { berupa tertib } \\
\text { disiplin dalam } \\
\text { kegiatan } \\
\text { kerohanian, mulai } \\
\text { ber-wudu', adzan, } \\
\text { shalat, berdzikir, } \\
\text { membaca al- } \\
\text { Qur'an, menghafal } \\
\text { surat-surat pendek, } \\
\text { ataupun tausiyah. }\end{array}$ & latihan berpidato. \\
\hline $\begin{array}{l}\text { Landasan } \\
\text { religius }\end{array}$ & $\begin{array}{l}\text { - Q.S. al-Hujurat } \\
\text { [49:12] tentang } \\
\text { perintah menjauhi } \\
\text { prasangka buruk, } \\
\text { mencari-cari } \\
\text { keburukan orang } \\
\text { lain, mengunjing, } \\
\text { dan bertakwa } \\
\text { - HR. Bukhari } \\
\text { tentang larangan } \\
\text { prasangka, hal ini } \\
\text { sebagai perkataan } \\
\text { paling dusta } \\
\text { - Q.S. al-Hujurat } \\
\text { [49:10] tentang } \\
\text { orang mukmin itu } \\
\text { bersaudara } \\
\text { - HR. Muslim } \\
\text { tentang } \\
\text { perumpamaan } \\
\text { orang mukmin } \\
\text { seperti satu tubuh }\end{array}$ & $\begin{array}{l}\text { - Q.S. al-Hujurat [49:10] tentang } \\
\text { orang mukmin itu bersaudara } \\
\text { - Q.S. al-Hujurat [49:11] tentang } \\
\text { larangan meren-dahkan } \\
\text { orang/kelompok lain, mencela } \\
\text { diri sendiri, maupun memanggil } \\
\text { orang lain dengan panggilan } \\
\text { yang buruk } \\
\text { - Q.S. al-Hujurat [49:12] tentang } \\
\text { perintah menjauhi prasangka } \\
\text { buruk, mencari-cari keburukan } \\
\text { orang lain, mengunjing, dan } \\
\text { bertakwa } \\
\text { - Q.S. al-Hujurat [49:13] tentang } \\
\text { saling mengenal (التحار) dan } \\
\text { takwa } \\
\text { - Hadits Muttafaq 'alaih tentang } \\
\text { larangan prasang-ka, hal ini } \\
\text { sebagai perkataan paling dusta } \\
\text { - HR. Muslim tentang anjuran } \\
\text { menjadi hamba Allah } \\
\text { bersaudara dan keharaman bagi } \\
\text { muslim, yaitu darah, harta, dan }\end{array}$ \\
\hline
\end{tabular}




\begin{tabular}{|c|c|c|}
\hline & & $\begin{array}{l}\text { kehormatannya } \\
\text { - Kitab 'Idhah al-Nasyi'in tentang } \\
\text { akhlak dalam kehidupan } \\
\text { beragama, berbangsa, dan } \\
\text { bernegara. } \\
\text { - Mahfudzat menjelaskan tentang } \\
\text { adab, diantaranya: (a) kebaikan } \\
\text { seseorang terletak pada ilmu dan } \\
\text { adab; (b) adab dalam majlis } \\
\text { ilmu; (c) menghilangkan } \\
\text { prasangka kepada Allah Swt, } \\
\text { dan segala sesuatu ada hik- } \\
\text { mahnya } \\
\text { - Tarbiyah wa Ta'lim tentang } \\
\text { pencapaian tujuan dengan } \\
\text { memperhatikan tiga hal: (a) } \\
\text { merenungkan amal; (b) jeli dan } \\
\text { mendalam melihat } \\
\text { permasalahan; dan (c) } \\
\text { mempersiapkan dengan baik }\end{array}$ \\
\hline $\begin{array}{l}\text { Nilai-nilai } \\
\text { dalam PAI }\end{array}$ & $\begin{array}{l}\text { - Menjauhi buruk } \\
\text { sangka } \\
\text { - Toleransi } \\
\text { - Demokrasi } \\
\text { - Etos kerja } \\
\text { - Adil } \\
\text { - Jujur } \\
\text { - Menghormati } \\
\text { orang tua dan guru } \\
\text { - Bertanggung jawab } \\
\text { - Lemah lembut } \\
\text { - Saling memaafkan }\end{array}$ & $\begin{array}{l}\text { - Menjauhi prasangka } \\
\text { - Toleransi } \\
\text { - Sabar } \\
\text { - Ulet } \\
\text { - Kerja keras } \\
\text { - Adil } \\
\text { - Jujur } \\
\text { - Berbakti kepada kedua orang } \\
\text { tua dan guru } \\
\text { - Berbuat kebajikan } \\
\text { - Tolong-menolong } \\
\text { - Pantang menyerah } \\
\text { - Tawadhu' } \\
\text { - Menghidari taklid buta }\end{array}$ \\
\hline $\begin{array}{l}\text { Mawas diri } \\
\text { (muhasabah) }\end{array}$ & $\begin{array}{l}\text { - Muhasabah } \\
\text { disesuaikan dengan } \\
\text { tema pembelajaran } \\
\text { pada KTSP }\end{array}$ & $\begin{array}{l}\text { - Q.S. al-Baqarah [2:284] tentang } \\
\text { perhitungan terhadap perbuatan } \\
\text { manusia } \\
\text { - Hadits Muttafaq 'alaih tentang } \\
\text { tidak menganggap remeh } \\
\text { nikmat Allah Swt. } \\
\text { - Mahfudzat tentang melihat }\end{array}$ \\
\hline
\end{tabular}




\begin{tabular}{|c|c|c|}
\hline & & $\begin{array}{l}\text { substansi pembi-caraan, bukan } \\
\text { pembicara-nya. } \\
\text { - Memperbaiki diri sendiri } \\
\text { - Elaborasi tahapan muha-sabah } \\
\text { melalui materi Sharaf, yaitu: } \\
\text { membantu (نصر), mendapat } \\
\text { masukan (ضرب), membuka diri } \\
\text { (فتم), menjadi tahu (علم), dan } \\
\text { melakukan kebaikan (حسب). } \\
\text { mengkalkulasi (حسب). }\end{array}$ \\
\hline $\begin{array}{l}\text { Pelaksanaan } \\
\text { tata tertib }\end{array}$ & $\begin{array}{l}\text { - Tata tertib sekolah } \\
\text { di-kelola oleh Tim } \\
\text { Tatib } \\
\text { - Sosialisasi dan } \\
\text { simulasi tata tertib } \\
\text { dilakukan pada } \\
\text { saat MPLS. } \\
\text { - Sosialisasi tata } \\
\text { tertib kepada } \\
\text { orangtua siswa } \\
\text { pada saat } \\
\text { pendaftaran } \\
\text { - Konsekuensi } \\
\text { penerapan tata } \\
\text { tertib berupa } \\
\text { "poin" bagi } \\
\text { pelanggar dan } \\
\text { "reward" bagi } \\
\text { yang melakukan } \\
\text { "kebaikan" } \\
\text { - Pengelolaan tata } \\
\text { tertib dilakukan } \\
\text { secara daring dan } \\
\text { manual. } \\
\text { - Hukuman fisik } \\
\text { berupa push-up } \\
\text { dan sit-up untuk } \\
\text { latihan pemanasan } \\
\text { dan kebugaran } \\
\text { - Tidak ada } \\
\text { hukuman atau }\end{array}$ & $\begin{array}{l}\text { - Sosialisasi tata tertib dilakukan } \\
\text { pada kegiatan pekan perkenalan } \\
\text { - Pengelolaan tata tertib } \\
\text { dilakukan secara manual } \\
\text { - Setiap siswa memperoleh Buku } \\
\text { Panduan Kegiatan Santri } \\
\text { (BPKS) dan Buku Pembiasaan } \\
\text { Santri } \\
\text { - Bagian Keamanan OPMI } \\
\text { terlibat dalam penerapan tata } \\
\text { tertib pada kegiatan } \\
\text { ekstrakurikuler, seperti latihan } \\
\text { pidato. } \\
\text { - Koordinator kepramukaan } \\
\text { bertanggung jawab dalam } \\
\text { penerapan tata tertib dalam } \\
\text { kegiatan pramuka } \\
\text { - Tata tertib di kelas menjadi } \\
\text { tanggung jawab guru dengan } \\
\text { memberikan apresiasi dan } \\
\text { sanksi }\end{array}$ \\
\hline
\end{tabular}









\begin{tabular}{|l|l|l|}
\hline & berperan sebagai & \\
"polisi" yang & \\
mengawasi siswa & \\
dalam & \\
melaksanakan tata & \\
tertib & \\
- Otoritas sanksi & \\
pada tim tatib, & \\
guru, dan wali & \\
kelas. & \\
\hline
\end{tabular}

Implementasi pengurangan prasangka akan membentuk individu dengan kesalehan multikultural. Multikultural difahami sebagai keragaman atau perbedaaan yang ada pada setiap individu. Sekecil apapun perbedaan, sesungguhnya dipengaruhi oleh kultur yang dimiliki individu masingmasing. Kesalehan multikultural mencakup: (a) kesalehan individu yang dilandasi dengan nilai-nilai religius dalam bersikap dan beramal kebaikan; (b) kesalehan spiritual dengan pengamalan keagamaan dalam kehidupannya sebagai hamba Allah Swt; dan (c) kesalehan sosial ditunjukkan adanya kemampuan berinteraksi sosial dalam masyarakat plural atau multikultur.

Berbagai upaya dilakukan untuk mengurangi prasangka dalam interaksi sosial, baik pemahaman terhadap nilai-nilai religiusitas, komunikasi antar warga sekolah, maupun penegakkan disiplin. Interaksi sosial di lingkungan sekolah tidak nampak adanya perlakuan "istimewa" terhadap kelompok siswa tertentu. Mereka menjalankan aktivitas berdasarkan peran dan tanggung jawabnya. Berbagai aktivitas dilakukan secara bersama untuk mencapai tujuan bersama dengan baik. Dampak kegiatan bersama adalah menumbuhkan rasa simpati dan empati yang dampak mengurangi prasangka buruk terhadap siswa lainnya.

Dalam tinjauan filosofi Jawa, siswa mampu menjadikan dirinya memiliki sifat-sifat priyayi, santri, petani, maupun saudagar. Sifat priyayi diimplementasikan dalam adab dan sopan santun dalam bertutur kata maupun dalam interaksi edukatif di sekolah. Sifat santri terlihat dalam menjalankan perintah agama maupun menjauhi larangannya, bersyukur atas karunia Allah Swt., dan sikap terhadap guru (ahli ilmu). Sifat petani ditunjukkan dengan etos kerja yang tinggi, jujur, sabar, dan berhati-hati. Dan sifat saudagar adalah mempertimbangkan setiap tindakan yang akan dilakukan.

Perspektif psikologis Kohlberg, penerapan tata tertib bagi siswa tergolong pada tahapan pre-konvensional (level I). Adanya beberapa indikator dalam pelaksanaan tata tertib, diantaranya: pertama, tata tertib 
dibuat oleh pihak sekolah. Dalam hal ini siswa tidak terlibat dalam pembuatan tata tertib. Hal yang terjadi adalah munculnya anggapan bahwa tata tertib berkaitan dengan punishment dan orientasi kepatuhan. Dan kedua, tata tertib dipandang berorientasi instrumental. Bilamana dilihat dari indikator bahwa siswa mendapat penghargaan (reward) dari "kebaikan" yang dilakukan, sehingga terdapat siswa yang meraih penghargaan terbaik. Realita ini menunjukkan peningkatan level yaitu konvensional, meskipun belum sepenuhnya peraturan dibuat dengan keterlibatan semua elemen komunitas sekolah.

Dimensi pengurangan prasangka dalam konteks pendidikan multikultural meliputi: (a) landasan religius dalam al-Qur'an dan sunnah. Keduanya menjadi pedoman dan panduan hidup umat Islam dalam kehidupannya; (b) ikatan akidah dalam persaudaraan sesama muslim; dan (c) menjaga hubungan baik dengan nonmuslim dalam konteks kemanusiaan. Nilai-nilai religius menjadi nilai universal dalam membangun hubungan sosial. Dalam konteks multikultural, hubungan antar manusia dari beragam latar belakang akan tetap terjaga dengan menjunjung tinggi nilainilai religius yang berlaku secara universal.

Dimensi pengurangan prasangka yang dikembangkan Banks, menurut hemat peneliti tidak menyinggung agama sebagai sumber nilai. Pola pengembangan dimensi pengurangan prasangka digambarkan berikut ini: 



\section{KESIMPULAN}

Dimensi pengurangan prasangka (prejudice reduction) dalam Islam didasarkan pada al-Qur'an dan Hadits tentang menjauhi prasangka atau berbaik sangka. Berbaik sangka dilandasi dengan pikiran positif terhadap orang lain maupun Tuhannya. Berpikir positif membentuk sikap mawas diri atau muhasabah diri. Muhasabah diri akan membentuk pribadi dalam ucapan dan tindakannya didasarkan pada nilai-nilai religius. Penerapan nilai-nilai religius dalam kehidupan pribadi maupun sosial membentuk kesalehan. Kesalehan individu dan kesalehan spiritual sebagai manifestasi pola hubungan makhluk dengan Tuhannya secara vertikal, dan memunculkan kesalehan sosial dalam masyarakat multikultural secara horizontal.

\section{DAFTAR PUSTAKA}

Abduh, Muhammad, and Muhammad Rasyid Ridha. Tafsir Al-Manar, Juz II. Cet. II. Qahirah: Dar al-Manar, 1947. 
Abu Zahrah, Muhammad. Zahrah Al-Tafasir. Qahirah: Dar al-Fikr al-Arabi, 1987.

Allport, G. W. The Nature of Prejudice. Reading. MA: Addison-Wesley, 1954.

Amrullah, Haji Abdulmalik Abdulkarim. Tafsir Al-Azhar, Jilid I. Singapura: Pustaka Nasional, 1982.

Anderson, Kristin J. Benign Bigotry: The Psychology of Subtle Prejudice. New York: Cambridge University Press, 2010.

Augoustinos, Martha, and Katherin J. Reynold. Understanding Prejudice, Racism, and Social Conflict. London: Sage Publication Inc, 2001.

Baghdadi, Shihab al-Din al-Sayid Mahmud al-Alusi al-. Ruh Al-Ma'ani Fi Tafsir Al-Qur'an Al-Karim Wa Al-Sab'i Al-Matsani, Juz II. BeirutLibanon: Dar Ihya al-Turats al-'Arabi, n.d.

Banks, James A. The Routledge International Companion to Multicultural Education. New York: Routledge, 2009.

Banks, James A., and Cherry A. McGee Banks. Multicultural Education: Issues and Perspectives. 7th ed. USA: John Wiley \& Sons, Inc., 2010.

Brown, Rupert. Prejudice: Its Social Psychology. 2nd. ed. United Kingdom: John Wiley \& Sons Inc, 2010.

Bukhari, Abu Abdillah Muhammad bin Isma'il bin Ibrahim bin al-Mughirah al-Ja'fi al-. Shahih Bukhari: Al-Jami’Al-Musnad Al-Shahih, Juz I. Beirut-Libanon: Dar al-Ta'shil, 2012.

Dimyati, Abu Bakar bin Muhammad Syatha al-. Kifayah Al-Atqiya' Wa Minhaj Al-Ashfiya'. Surabaya: al-Hidayah, .

Fauzan, Abdullah bin Shalih al-. Minhah Al-'Allam Fi Syarh Bulugh AlMaram, Juz X. Cet. I. Qahirah: Dar Ibn al-Jauzy, 1432.

Ghazali, al-Imam Abi Hamid bin Muhammad bin Muhammad al-. Ihya' Ulum Al-Diin, Juz II. Bi Qalam Badawi Thabanah. Semarang: Karya Toha Putra, n.d.

Goffee, Robert, and Gareth Jones. Why Should Anyone Work Here?: What It Takes to Create an Authentic Organization. Boston: Harvard Business Review Press, 2015.

Grant, Carl A., and Christine Sleeter. Doing Multicultural Education for Achievement and Equity. USA: Taylor \& Francis Group, 2007. 
Haitsami, Abu al-Hasan Ali bin Abi Bakr bin Sulaiman al-Syafi'i Nur alDin al-. Majma'u Al-Zawaid Wa Manba'u Al-Fawaid, Juz XVI. Tahqiq wa Takhrij Husein Salim Asad al-Darani, Cet. I. Jeddah: Dar al-Minhaj, 2015.

Harding, J. Proshansky, H.M. Kuter B., and Chein. "Prejudice and Ethnic Relations." Reading MA; Addison Wesley, The Handbook of Social Psychology, Vol.5 (1969): 1-76.

Hasani, Ahmad bin Muhammad bin 'Ajibah al-. Iqadh Al-Himam Fii Syarh Al-Hikam. Taqdim wa Muraja'ah Muhammad Ahmad Hasabullah. Kairo: Dar al-Ma'arif, n.d.

Ibn Jama'ah, al-Imam al-Qadhi Badruddin Muhammad bin Ibrahim bin Sa'dillah. Tadzkirah Al-Sami' Wa Al-Mutakallim Fii Adab Al-'Alim Wa Al-Muta'alim. I'tana bihi Muhammad bin Mahdi al-'Azmy, Cet. III. Beirut-Libanon: Dar al-Basyair al-Islamiyah, 2012.

Ibnu Hajar al-'Asqalani, al-Imam al-Hafidz Ahmad bin 'Ali. Bulugh AlMaram Min Adillah Al-Ahkam. Haqqaqah wa Syarahah wa 'Allaqa 'alaih Syeikh Usamah Shalahuddin, Cet. I. Beirut-Libanon: Dar Ihya al-Ulum, 1991.

Ibnu Katsir, al-Hafidz. Umdah Al-Tafsir, Juz I. Tahqiq Ahmad Syakir, Cet. II. Dar al-Wafa, 2005.

Ibnu Taimiyah, Abi al-Abbas Ahmad bin Abd al-Halim. Fashl Fii Tazkiyah Al-Nafs. I'tana bih Fawwaz Muhammad al-'Audhi, Ct. I. Kuwait: Maktabah al-Nahj al-Wadhih, 2018.

. Tazkiyah Al-Nafs. Dirasah wa Tahqiq Muhammad bin Said bin Salim al-Qahthani, Cet. I. Riyadh: Dar al-Muslim, 1994.

Jauzi, Abu al-Faraj Jamal al-Din bin Abdurrahman bin Ali bin Muhammad al-. Zad Al-Masir Fi Ilm Al-Tafsir. Cet. I. Beirut-Libanon: Dar Ibnu Hazm, 2002.

Jumbangi, al-Syeikh Muhammad Hasyim al-Asy'ari al-. Adab Al-'Alim Wa Al-Muta'allim. Cet. I. Jombang: Maktabah al-Turats al-Islami, 1415.

Kite, Mary E., and Bernard E. Whitley, Jr. Psychology of Prejudice and Discrimination. 3rd. ed. New York: Routledge, 2016.

Kurdi, Muhammad Amin al-. Tanwir Al-Qulub Fi Mu'amalah Allam AlGhuyub. Taqdim Abdullah Mas'ud, Cet. I. Suriah: Dar al-Qalam alArabi, 1991. 
Madani, Muhammad Hayah al-Sindi al-. Syarh Al-Hikam Al-Athaiyah. Tahqiq Nizar Hamadi, Cet. I. Beirut-Libanon: Dar Maktabah alMa'arif, 2010.

Maksum, Ali, and Luluk Yunan Ruhendi. Paradigma Pendidikan Universal. Yogyakarta: IRCiSoD, 2004.

Maraghi, Ahmad Musthafa al-. Tafsir Al-Maraghi, Juz II. Cet. I. Kairo: Musthafa Al-Babi Al-Halabi, 1946.

Mulkhan, Abdul Munir. Kesalehan Multikultural: Ber-Islam Secara Autentik-Kontekstual Di Aras Peradaban Global. Jakarta: PSAP Muhammadiyah, 2005.

Nawawi al-Jawi, al-Allamah al-Syeikh Muhammad bin Umar. Marah Labid Li Kasyf Ma'na Al-Qur'an Al-Majid, Juz I. Dhabathahu wa Shahahu wa Wadha'a Hawasyih Muhammad Amiin al-Dhanawi, Cet. I. Beirut-Libanon: Dar al-Kutub al-Ilmiah, 1997.

Nidi, Muhammad Khalil al-Khatib al-. Kasyf Al-Ghitha': Syarh Wa Tartib Wa Nadhm Hikam Sayyidi Ahmad Bin Athailah Al-Sakandari. Dar al-Basyirah li al-Tsaqafah wa al-Ulum, n.d.

Qardhawi, Yusuf. Al-Qur'an Berbicara Tentang Akal Dan Ilmu Pengetahuan. "al-'Aql wa al-Ilm fii al-Qur'an al-Karim", terj. Abdul Hayyi al-Khattani, Irfan Salim, dan Sochimien, Cet. I. Jakarta: Gema Insani Press, 1998.

Qardhawi, Yusuf al-. Al-Aql Wa Al-Ilm Fi Al-Qur'an Al-Karim. Cet. I. Qahirah: Maktabah Wahbah, 1996.

Qasimi, Muhammad Jamal al-Din al-. Mahasin Al-Ta'wil. Cet. I. Dar Ihya al-Kutub al-Arabiyah, 1957.

Razi, Muhammad Fakhr al-Din al-. Tafsir Al-Fakhr Al-Razi, Juz IV. Cet. I. Beirut-Libanon: Dar al-Fikr, 1981.

Rumi, Yaqut al-Hamawi al-. Mu'jam Al-Udaba': Irsyad Al-Arib Ila Ma'rifah Al-Adib. Tahqiq Ihsan Abbas, Cet. I. Beirut-Libanon: Dar al-Gharb al-Islami, 1993.

Rundi, Ibnu 'Abbad al-Naffazi al-. Al-Hikam Al-'Athai'iyah Li Ibn 'Athaillah Al-Sakandari. I'dad wa Dirasah Muhammad Abd alMaqshud Haikal, Cet. I. Qahirah: Mu'asasah al-Ahram, 1988.

—. Syarh Al-Hikam Ala Matn Al-Hikam Li Imam Ahmad Bin Muhammad Bin Abdil Karim Ibn Atha 'illah Al-Sakandari, n.d. 
Sandel, Adam Adatto. The Place of Prejudice: A Case for Reasoning Within The World. USA: Harvard University Press, 2014.

Sunandar, Asep (ed). Prof. Son Sang Pendidik Multikultural. Cet. I. Malang: Intelegensia Media, 2015.

Suryana, Yaya, and A. Rusdiana. Pendidikan Multikultural: Suatu Upaya Penguasaan Jati Diri Bangsa, Konsep, Prinsip, Implementasi. Bandung: Pustaka Setia, 2015.

Taguieff, Pierre-André. The Force of Prejudice: On Racism and Its Doubles. Translated and edited by Hassan Melehy. London: The University of Minnesota Press, 2001.

Tamar, Muhammad Muhammad. Muqaddimah Al-Imam Al-Nawawi: Li Kitab Al-Majmu' Syarh Al-Muhadzab. Cet. I. Kairo: Maktabah alBalad al-Amiin, 1999.

Thabari, Abu Ja'far Muhammad bin Jarir al-. Tafsir Al-Thabari: Jami' AlBayan 'an Ta'wil Ai Al-Qur'an, Juz II. Tahqiq Abdullah bin Abd alMuhsin al-Turki, Cet. I. Qahirah: Markaz al-Buhuts wa al-Dirasat alArabiyah wa al-Islamiyah, 2001.

Thibi, Saraf al-Din al-Husein bin Abdillah al-. Futuh Al-Ghaib Fi Al-Kasyf an Qina' Al-Raib, Juz III. Tahqiq Umar Hasan al-Qiyam, Cet. I. Dubai: al-Imarat al-Arabiyah al-Muttahidah, 2013.

Tsalabi, Abu Ishaq Ahmad bin Muhammad bin Ibrahim al-. Al-Kasyf Wa AlBayan Fi Tafsir Al-Qur'an, Juz I. Tahqiq Sayyid Kasrawi Hasan, Cet. I. Beirut-Libanon: Dar al-Kutub al-Ilmiah, 2004.

Ulaimi, Mujir al-Din bin Muhammad al-'. Fath Al-Rahman Fi Tafsir AlQur'an, Juz I. Tahqiq wa Takhrij Nuruddin Thalib, Cet. I. Beirut: Dar al-Nawadir, 2009.

Utsaimin, Muhammad bin Shalih al-'. Fath Dzi Al-Jalal Wa Al-Ikram Bi Syarh Bulugh Al-Maram, Juz VI. Tahqiq wa Ta'liq Shubhi bin Muhammad Ramadhan wa Ummu Isra' binti Arafah Baiyumi, Cet. I. Qahirah: al-Maktabah al-Islamiyah, 2006. 